DOI: 10.20472/TEC.2019.007.010

PARAMJEET KAUR MANGAT

Smt. Jawala Devi College of Education, India

\title{
ACADEMIC PROCRASTINATION AMONG HIGH SCHOOL STUDENTS IN RELATION TO PEER PRESSURE
}

\begin{abstract}
:
The study aimed to examine the Academic Procrastination among High School students in relation to their Peer Pressure. Descriptive survey method of research was employed for this study. Data was collected by randomization technique of sampling from a sample of 400 high school students of Punjab state, out of which 200 students were from government school and 200 students were from private schools. Tools used in this study were Academic Procrastination Scale: A. K. Kalia and Manju Yadav and Peer Pressure Scale [PPS-SS] by Saini and Singh. The data was analyzed by employing descriptive statistics like Mean, Median, Mode, SD, Skewness, Kurtosis, t-ratio and Karl Pearson's coefficient of correlation. On the bases of data analyzed, no significant difference has been found in academic procrastination and peer pressure of government and private high school students. Further no significant difference has been found in academic procrastination of male and female high school students. Further no significant relationship has been found in academic procrastination and peer pressure of total high school students.
\end{abstract}

\section{Keywords:}

ACADEMIC PROCRASTINATION, PEER PRESSURE 
Human behavior falls within a range of being common, unusual, and acceptable and beyond acceptable limits. The acceptability of behavior depends heavily upon social norms and is regulated by various means of social control. Moreover, the three domains related to human behavior are - cognitive (thinking), affective (emotion/feeling), and psychomotor (physical/kinesthetic). The present has been proposed to explore the tendency of adolescents' behavior in terms of the level of academic procrastination in relation to their peer pressure.

\section{OPERATIONAL DEFINITION OF KEY TERMS}

The operational definitions have been stated as under:

ACADEMIC PROCRASTINATION: Academic procrastination is defined as "an irrational tendency to delay at the beginning or completion of an academic task. Academic task will include assignments, examination, project work, presentations, library activities and co-curricular activities etc.

PEER PRESSURE: Peer pressure is a term used to describe a feeling that one must do the same things as other people of one's age and social group in order to be liked or respected by them. It is a human tendency to do what the crowd does.

\section{REVIEW OF RELATED LITERATURE:}

Klassen and Kuzucu (2009) conducted a study on academic procrastination and motivation of adolescents in Turkey. This article presents a study of academic procrastination and associated motivation variables in 508 adolescents from a general secondary school in central Turkey. There was no difference in the levels of procrastination of boys and girls. Most participants (83\%) reported one hour or more procrastinating per day, with writing tasks being most prone to procrastination for boys and girls. When procrastinating, Turkish adolescent boys were more likely to spend time with electronic media (watching TV, emailing, going on-line, and, in particular, playing computer games), whereas girls were most likely to read books, magazines, and newspapers.

Oni (2010) investigated peer group pressure as a determinant of adolescents' social adjustment in Nigerian schools, with a focus on the Ikeja local government area of Lagos State. Two null hypotheses were tested using a random sample of one hundred and twenty adolescents from four secondary schools in the lkeja local government area. The instrument was a self-designed questionnaire. The collected data were analyzed using an independent t-test and a Pearson Product Moment Correlation Coefficient. The results of the analysis showed that peer group pressure among adolescents is related to their social adjustment and that the gender of the adolescents affects their 85 social adjustments as well. Based on these findings, the following recommendations are made: parents should serve as role models for their children to emulate; parents should be watchful of the types of friends kept by their adolescent children; and parent-child relationship should be cordial enough to permit 
adolescents in discussing their problems with them. In addition, the management of adolescents (secondary school students) should be the joint responsibility of parents, guidance counselors, school administrators and society at large.

According to Firouzeh and Jalil (2011) procrastination is a weak point of personality and leads to low self-confidence. Perception of university students of themselves as procrastinator varies according to different researcher as it is $95 \%$ reported by Ellis and Knaus (1977), 46\% by Solomon and Rothblum (1984) and 75\% reported by Potts (1987). Furthermore, studies also concluded that the most of the students demonstrated unrelenting and consistent procrastination in daily study activities (Day et al., 2000). It is seen among university students that they use to bunk classes (Rothblum et al., 1986), have low academic performance (Fritzsche et al., 2003) and tardiness (Lay, 1986; Rothblum et al., (1986).

Khan et al, (2014) conducted a study on academic procrastination among male and female university and college students. Effect of some demographic variables like gender, age and education were also explored. Sample consisted of 200 students (100 college students and 100 university students) from different colleges and universities of Islamabad. Their age ranged between 16 to 27 years. Tuckman Procrastination Scale (TPS) (Tuckman, 1991) was used to collect data. Results indicated significant difference on demographic variables of age, gender and education. Specifically, a significant difference was found among males and females on academic procrastination. The results further show that college students tend to procrastinate more than university students.

\section{RATIONALE OF THE STUDY}

Procrastination is a tendency to postpone when it is necessary to reach goal (Lay, 1986). The growing body of literature has demonstrated it as a personality characteristic far more than time management (Ferrari et al, 1995). It is a complex process with affective, cognitive and behavioral components (Rothblum et al, 1986). Procrastination appears to be a significant problem although there are many possible reasons for the occurrence of procrastination in students. It is seen in our daily life that students generally delay the academic task by engaging themselves in some other activities like using electronic media, watching movie, playing games, enjoying with friends, peers etc. On other hand, they also delay the academic task due to lack of interest in life, academic stress, anxiety etc. It's a major issue of the hour that what are the factors responsible for procrastination among students now a days ? How it is related with Peer Pressure? Is Procrastination the influence of their peer group, Peer pressure or some another reason like academic stress provokes them to procrastinate and how much actually procrastination found among high school students? Keeping in mind the whole scenario, the following problem emerged in the mind of the investigator. The study will help the teachers, parents and other concerned persons to deal with the students, providing suitable measures to them by knowing the reason of procrastination. Moreover, there is a paucity of literature regarding Peer Pressure as predictors of Academic Procrastination and also there exists lack of research in Indian 
context as little researches have been done in this part of country in the present combination of variables. The present study endeavors to fill these research gaps. Hence, research is needed to understand the individual contribution of Peer Pressure on academic procrastination of high school students.

\section{STATEMENT OF THE PROBLEM}

The problem under investigation is stated below:

ACADEMIC PROCRASTINATION AMONG HIGH SCHOOL STUDENTS IN RELATION TO PEER PRESSURE

\section{OBJECTIVES OF THE STUDY}

Following are the objectives of the present study:

1. To study the difference in Academic Procrastination of government and private high school students.

2. To study the difference in Peer Pressure of government and private high school students.

3. To study the difference in Academic Procrastination of male and female high school students.

4. To study the difference in Peer Pressure of male and female high school students.

5. To find out the correlation between Academic Procrastination and Peer Pressure of high school students.

\section{HYPOTHESES OF THE STUDY}

Following hypothesis have been framed on the bases of above objectives:

1. There exists no significant difference in Academic Procrastination of government and private high school students.

2. There exists no significant difference in Peer Pressure of government and private high school students.

3. There exists no significant difference in Academic Procrastination of male and female high school students.

4. There exists no significant difference in Peer Pressure of male and female high school students.

5. There exists a significant relationship between Academic Procrastination and Peer Pressure of high school students.

\section{DELIMITATIONS OF THE STUDY}

The study will be limited in the following aspects: 
1. The study will be limited to 400 high school students only.

2. The study will be limited to the students of class $9^{\text {th }}$ only.

3. The study will be limited to 200 private school students and 200 government school students.

4. The study will be limited to 200 male and 200 female high school students.

5. The study will be confined to schools affiliated to Punjab School Education Board only.

6. The study will be confined to Fatehgarh Sahib district of Punjab state only.

\section{METHOD AND PROCEDURE OF THE STUDY}

Descriptive Survey method was used by the investigator to collect the relevant information for research. Standardized tools were used to collect the primary data. Total 400 students were picked randomly from twenty schools of Fatehgarh Sahib district of Punjab state, India, out of which ten schools were from government and ten schools were private. Twenty students were picked randomly from each school. In order to collect data, investigator took written permission from principals of selected Schools. It has been assured to the students by the investigator that the data provided by the students will be kept confidential. Verbal instruction was given to the students by the investigator to fill all the questionnaire. Descriptive and Inferential statistics was used to analyze the data in quantitative terms.

DESCRIPTION OF THE SAMPLE: Sample size of the study was 400 . Multistage random sampling method was used for present study. Distribution of Sample in present study will be as follows:

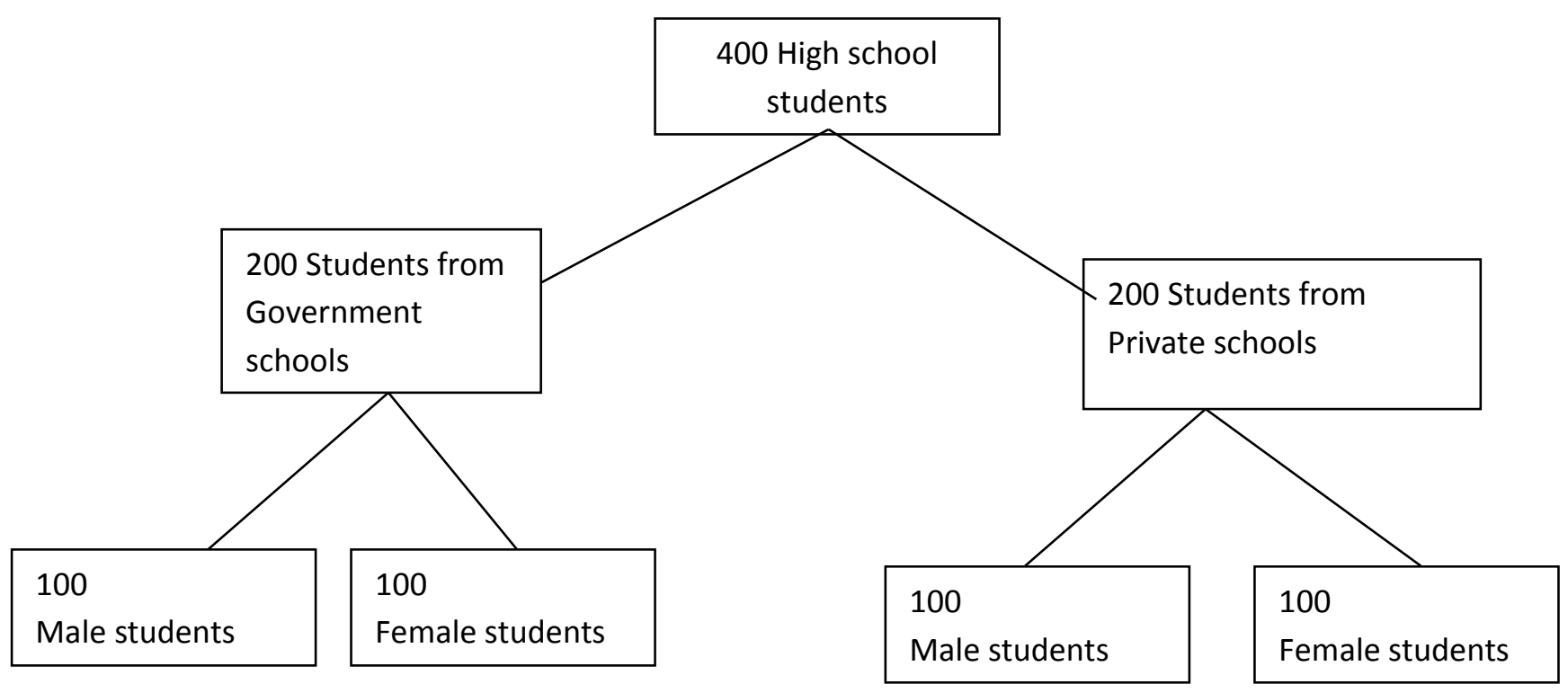

TOOLS USED:

1. Academic Procrastination Scale: A. K. Kalia and Manju Yadav. [2015].

2. Peer Pressure Scale [PPS-SS] by Saini and Singh (2010). 


\section{DATA ANALYSIS AND INTERPRETATIONS:}

In order to visualize the nature of score distribution of the data collected, numerical determinates of normality like Mean, Median, Mode, and Standard Deviation, are worked out. t-test was carried out to draw inferences from the data and test the hypotheses. Karl Pearson's Product moment method of correlation was used to find out the correlation between two variables. After the analysis of data, following conclusion were made.

"Table 1: Showing Mean differences in Academic Procrastination of government and private high school students"

\begin{tabular}{|c|c|c|c|c|c|c|}
\hline & mean & median & SD & skewness & Kurtosis & t-ratio \\
\hline Government & 65.52 & 65.5 & 13.023 & -0.516 & -0.583 & 0.728 \\
\hline Private & 64.88 & 65 & 12.286 & -0.262 & -1.018 & \\
\hline
\end{tabular}

Non Significant at $0.05 \& 0.01$ level

Table 1 shows the mean scores of academic procrastination of government and private high school students as 65.52 and 64.88 respectively and their standard deviation as 13.023 and 12.286 respectively. The t-ratio was calculated as 0.728 which is less than the table value at 0.05 level of confidence. Hence the government and private High school students do not differ significantly in their Academic procrastination.

Hence the hypothesis 1 which states that "There exists no significant difference in Academic Procrastination of government and private high school students" is accepted.

"Table 2: Showing Mean differences in Peer Pressure of government and private high school students"

\begin{tabular}{|c|c|c|c|c|c|c|}
\hline & Mean & Median & SD & skewness & Kurtosis & t-ratio \\
\hline Government & 70.88 & 71 & 11.142 & -0.198 & -0.381 & \multirow{2}{*}{0.116} \\
\cline { 1 - 6 } Private & 68.38 & 68 & 11.765 & 0.005 & -0.388 & \\
\hline
\end{tabular}

Non-significant at 0.05 level \& 0.01 level

Table 2 shows the mean scores of Peer Pressure of government and private high school students as 70.88 and 68.38 respectively and their standard deviation as 11.142 and 11.765 respectively. The t-ratio was calculated as 0.116 which is less than the table value of 1.96 at 0.05 level of confidence and also less than the table value of 2.58 at 0.01 level of confidence.

Hence government and private high school students do not differ significantly from each other in their Peer Pressure.

Hence the hypothesis 2 which states that "There will be no significant difference in Peer Pressure of government and private high school students" is accepted. 
"Table 3: Showing Mean differences in Academic Procrastination of male and female high school students"

\begin{tabular}{|c|c|c|c|c|c|c|}
\hline & Mean & Median & SD & skewness & kurtosis & t-ratio \\
\hline Male & 68.07 & 72 & 12.625 & -0.746 & -0.083 & \multirow{2}{*}{0.003} \\
\cline { 1 - 5 } Female & 62.33 & 62 & 12.037 & -0.133 & -1.116 & \\
\hline
\end{tabular}

*Non Significant at 0.05 level of confidence

Table 3 shows the mean scores of Academic Procrastination of male and female high school students as 68.07 and 62.33 respectively and their standard deviation as 12.625 and 12.037 respectively. The t-ratio was calculated as 0.003 which is less than the table value at 0.05 and 0.01 level of confidence.

Hence the male and female high school students do not differ significantly in their academic procrastination.

Hence the hypothesis 3 which states that "there is no significant difference in academic procrastination of male and female high school students" is accepted.

"Table 4: Showing Mean differences in Peer Pressure of male and female high school students"

\begin{tabular}{|c|c|c|c|c|c|c|}
\hline & mean & median & SD & skewness & kurtosis & t-ratio \\
\hline Male & 66.06 & 67 & 11.361 & 0.097 & -0.221 & \multirow{2}{*}{$7.721^{*}$} \\
\cline { 1 - 6 } Female & 73.2 & 73 & 10.542 & -0.228 & -0.397 & \\
\hline
\end{tabular}

Significant at 0.05 level

Table 4 shows the mean scores of Peer Pressure of male and female high school students as 66.06 and 73.2 respectively and their standard deviation as 11.361 and 10.542 respectively. The t-ratio was calculated as 7.721 which is higher than the table value at 0.05 level and 0.01 level of confidence.

Hence the male and female high school students differ significantly in their peer pressure.

Hence the hypothesis 4 which states that "There exists no significant difference in Peer Pressure of male and female high school students" is rejected.

"Table 5: Coefficient of correlation between Academic Procrastination and Peer Pressure of total sample"

\begin{tabular}{|c|c|c|c|c|c|c|}
\hline & Mean & Median & SD & skewness & kurtosis & $\begin{array}{c}\text { Coefficient of } \\
\text { correlation }\end{array}$ \\
\hline $\begin{array}{c}\text { Academic } \\
\text { Procrastination }\end{array}$ & 65.2 & 65 & 12.663 & -0.392 & -0.794 & 0.0008 \\
\hline Peer Pressure & 69.63 & 71 & 11.526 & -0.103 & -0.428 & \\
\hline
\end{tabular}

Table 5 shows the coefficient of correlation between Academic Procrastination and Peer Pressure of total high school students. The value of coefficient of correlation is 0.0008 which is less than the table value of 0.159 at 0.05 level of confidence. 
Hence the hypothesis 5 which states "There exists a significant relationship between Academic Procrastination and Peer Pressure of high school students" is rejected.

\section{Suggestions for further research}

The present study opens up certain avenues for further research which are briefly listed below:-

1. The present study was conducted on a sample of 400 high school students. A similar study may be conducted on a large sample for broader generalization.

2. Academic Procrastination can also be studied in relation to some other variables such as emotional intelligence, personality traits etc.

3. A cross cultural study may be conducted on the variables of academic procrastination and peer pressure

4. The present study was confined to district Fatehgarh sahib of Punjab state only. A similar study may be conducted in other cities and districts of the state.

5. The present study was conducted on schools affiliated to Punjab School Education Board only. Similar study can be conducted on school affiliated with various bodies/boards.

\section{REFERENCES:}

Akinsola, M., Tella, A. \& Tella, A. (2007). Correlates of academic procrastination and mathematics achievement of undergraduate students. Eurasia Journal of Mathematics, Science \& Technology Education, 3(4), 363-370.

Ferrari, J. R., Johnson, J. L. \& McCown, W. G. (1995). Procrastination and task avoidance: Theory, research and treatment. New York, NY: Plenum Press.

Firouzeh, S. \& Jalil, J. F. (2011). The Effects of Coping Styles and Gender on Academic Procrastination among University Students. Journal of Basic and Applied Scientific Research, 1(12), 2987 2993.

Kalia, A.K. \& Yadav, M. (2015). Manuel of Academic Procrastination Scale (APS-KAYM), Agra: National Psychological Corporation.

Khan, M. J., Arif, H., Noor, S. S. \& Muneer, S. (2014). Academic Procrastination among Male and Female University and College Students. Journal of Social Sciences, 8(2), 65-70

Klassen, R. \& Kuzucu, E. (2009). Academic procrastination and motivation of adolescents in Turkey. Educational Psychology, 29(1), 69-81.

Saini, S. \& Singh, S. (2010). Manuel of Peer Pressure Scale [PPS-SS]. Agra: National Psychological Corporation.

Rothblum, E. D., Solomon, L. J. \& Murakami, J. (1986). Affective, cognitive, and behavioral differences between high and low procrastinators. Journal of Counseling Psychology, 33(4), 387-394.

Oni, A. A. (2010). Peer group pressure as a department of adolescent social adjustment in Nigerian schools. Asian Pacific Journal of Educators and Education, 25, 189-202. 